IRSTI 68.37 .13

\author{
${ }^{1,2}$ Alemyar S., ${ }^{1 *}$ Habibi A., ${ }^{1}$ Akimbekov N.Sh. \\ ${ }^{1}$ Department of Biotechnology, Biology and biotechnology faculty of \\ al-Farabi Kazakh National University, Kazakhstan, Almaty \\ ${ }^{2}$ Department of Plant Science, Agriculture faculty of Alberoni University, \\ Afghanistan, Kapisa \\ *e-mail: ainullah.habibi1@yahoo.com

\section{EFFECT OF HYSSOP EXTRACT AGAINST MICROORGANISMS ISOLATED FROM WHEAT GRAINS}

The hyssop essential oils have been widely used as bactericidal, fungicidal, antivirus and insecticidal agents. On the other hand, the main method to control bacterial contamination is using synthetic bactericide, but the development or conjugation of bacteria resistance to chemical products, the high operational cost and environmental pollution have created the need for developing alternative approaches to control many microbial contamination, especially bacterial and in this sense the essential oils of hyssop is an alternative to control many pathogenic bacteria.

Because of a growing concern about relationships between diet and diseases and a growing need to improve the quality and safety of food supply, research is to define conditions that minimize the levels of microbial effect compounds wheat germination and growth. Essential oil of hyssop (Hyssopus officinalis) revealed one of the best biological compounds which control the pathogenic fungal, viral, bacterial and insect contamination. The results of this experiment displayed essential oils were fully effectiveness on bacterial inoculant and support the growth of wheat grain. It capable to eliminated the all pathogenic bacteria which inoculated with seeds.

The experiment displayed that bacterial inoculant effected on seed germination, only two varieties of wheat capable to geminate with Pseudomonas inoculated that was $40 \%$ in Ghory cultivar and $80 \%$ in Sulh variety. Thus shown bacterial inoculated able to decrease 60 and 20 percentage germination of the Ghory and Sulh varieties. Although in all other wheat cultivars hadn't germination in bacterial inoculated variant, but in controls (inoculant of water, inoculated with essential oil of hyssop) had $100 \%$ germination and also in treated variants had $>80 \%$ germinated and were greatly treated by essential oil of hyssop (Hyssopus officinalis).

Key word: essential oils, environmental pollution, bacterial inoculant, wheat grain, hyssop.

\author{
1,2Алемьяр С., ${ }^{1 *}$ Хабиби А., ${ }^{1}$ Акимбеков Н.Ш. \\ 'Биотехнология кафеАрасы, биология және битехнология факультеті, \\ әл-Фараби атындағы Қазақ, ұлттық университеті, Қазақстан, Алматы қ. \\ Өсімдік шаруашылығы кафедрасы, ауыл шаруашылығы факультеті, \\ әл-Берони университеті, Ауғанстан, Капис қ. \\ *e-mail: ainullah.habibi1@yahoo.com \\ Бидай дәндерінен бөлініп амынған микроорганизмдерге \\ иссоп сығындысының әсерін зерттеу
}

Иссоптың эфир майлары бактерицидтік, фунгицидтік, антивирустық, және инсектицидтік агент ретінде кеңінен қолданылады. Негізінен, әртүрлі бактериялық аурулармен күресудің басты әдісі ретінде синтетикалық бактерицидтер қолданылады, алайда бактериялардың химиялық препараттарға төзімділігінің артуы, жоғары эксплуатациялық шығын және қоршаған ортаны ластауы микробты зиянкестердің өсуін бақылайтын қосымша жаңа үдерісті жасау керектігін қажет етеді, осы орайда иссоптың эфир майлары ауылшаруашылық дақылдарын қорғауда нағыз қажетті әдістің бірі ретінде қарастыруға болады. Сонымен қатар, токсинді заттар мен зиянды микроорганизмдермен мастанған тамақтанудың рационы қазіргі таңда өте жоғары 
алаңдаушылық тудырып отыр. Әсіресе, патогенді және шартты-патогенді микроорганизмдердің көбеюі әртүрлі аурулардың пайда болуына алып келді, олар әдетте сақтау барысында бидай дәні мен бидай өнімдерінің жылдам бүлінуіне соғады. Иссоп (Hyssopus officinalis) эфир майының құрамында саңырауқұлақтар, вирустар, бактериялар мен споралардың өсуін шектейтін ерекше биологиялық қосылыстар бар. Жұмыстың нәтижелері эфир майының микроорганизмдердің өсуін толық тежейтін және билай тұқымының өсуіне ешқандай кері әсер бермейтіндігін көрсетті. Тәжірибеде бидай тұқымдарының өнуі мен өсуін 5 күн барысында бақыланды.

Алынған нәтижелер бидайдың басқа сорттарымен салыстырғанда тек гури мен сулх сорттары бактериялық, инокулят Pseudomonas sp. қатысында өсуге қабілетті екенАігін көрсетті, тұқымдардың өнуі сәйкесінше 40\% және 80\% құрады. Олай болса, Pseudomonas sp. бактериясы клеткаларымен инокуляцияланған өсімдіктердің тұқымдары өте темен өсу көрсеткіштеріне ие болды. Егуге дейінгі тұқымдарды иссоптың эфир майларымен өндеу оның өнуі мен тамыр жүйесінің өсуін > 80\% белсендірді, әрі марфометриялық көрсеткіштерін өзгерісіне алып келАі.

Түйін сөздер: эфир майлары, қоршаған ортаның ластауы, бактериялық инокулят, бидай тұқымы, иссоп.

\author{
1,2Алемьяр С., ${ }^{1 *}$ Хабиби А., ${ }^{1}$ Акимбеков Н.Ш. \\ ${ }^{1}$ Кафедра биотехнологии, факультета биологии и биотехнологии \\ Казахского национального университета имени аль-Фараби, Казахстан, г. Алматы \\ ${ }^{2}$ Кафедрра растениеводства, факультет сельского хозяйства \\ Университета аль-Берони, Афганистан, г. Каписа \\ *e-mail: ainullah.habibi1@yahoo.com
}

Изучение влияния экстракта иссопа на микроорганизмы, выделенные из зерна пшеницы

\begin{abstract}
Эфирные масла иссопа широко применяются в качестве бактерицидных, фунгицидных, антивирусных и инсектицидных агентов. С Аругой стороны, основным методом борьбы с бактериальными заболеваниями является синтетический бактерициА, но формирование и развитие устойчивости бактерий к химическим препаратам, высокие эксплуатационные затраты и загрязнение окружающей среды повышают потребность в разработке а^ьтернативных подходов к процессу контроля микробной обсемененности, и в этом отношении эфирные масла иссопа являются Аополнительным способом защиты сельскохозяйственных культур.

Все большую озабоченность вызывают нездоровый рацион питания, загрязненные токсическими веществами и вредными микроорганизмами. Последнее крайне актуально, поскольку с ростом патогенных и условно-патогенных бактерий значительно участились случаи различных заболеваний, а их обсемененность вызывает быструю порчу зерна и продуктов при хранении. В составе эфирного масла иссопа (Hyssopus officinalis) обнаружено одно из мучших биологических соединений, которое контролирует рост патогенных грибов, вирусов, бактерий и спор. Результаты этой работы показали, что эфирные масла полностью подавляют рост микроорганизмов, при этом не оказывают никакого отрицательного воздействия на зерна пророщенной пшеницы. В ходе эксперимента проводились наблюдения за прорастанием семян в течение пяти Аней.

Полученные Аанные показали, что только Ава сорта пшеницы Гури и Сулх способны прорастать при условии наличия бактериального инокулята Pseudomonas sp., развитие семян при этом составляет соответственно 40\% и 80\%. Таким образом, показано, что растения, инокулированные клетками бактерии Pseudomonas sp., имеют низкий темп роста. Предпосевная обработка семян эфирным маслом иссопа (Hyssopus officinalis) привела к повышению активности прорастания, роста и развития корневой системы на $80 \%$ и изменение морфометрических показателей.
\end{abstract}

КАючевые слова: эфирные масла, загрязнение окружающей среды, бактериальный инокулят, пшеничное зерно, иссоп.

Wheat (Triticum aestivum L.) has taken place as a staple food source for humanities since times immemorial (Satish S., et al., 2010: 237-241). It is considered as a major agricultural commodity and dietary component across the world and it is one of the most significant cereals in view of nutritional value (Abd El-Baky H., et al., 2009:
77-83). Pathogenic microbes cause root infection (rots), wilts and damping off diseases which are a huge problem in agricultural production worldwide. Intensive production with successive cultivations of susceptible crops often results in the arise of high population densities of pathogenic microbes Soilborne pathogens cause economically important 
diseases in planted crops such as damping-off, root rots, seedling blights, crown rots, foot rots, root browning and wilts. The diseases may be caused by more than 50 different fungal species, various bacterial species and viruses. The damage evoked by soil borne pathogens is usually under estimated, since it appears below ground. Plant diseases caused by pathogens below ground may be considered as limiting factors of plant health and save yield quantities and qualitatively. Function of fungicides and bactericide to control soil-borne fungal and bacterial pathogens, with the exception of seed treatments, seems not to be appropriate for economic and ecological reasons (Abawi G. and TL Widmer 2000: 37-47, Bonanomi et al., 2006: 571-578, Macias et al., 2007: 327-348). Efficiency of field crops should be increased to meet the rising global demand for agricultural products. In agricultural farms, pathogenic bacteria are responsible for a sizable part of the economic loss by means of reducing the quality and quantity of the products (Rassaeifar M., et al., 2013: 73-81).

Infested wheat grains are the carry pathogens which can have long-distance diffusion. The major impact of seed-borne diseases in wheat is not only yield reduction but also deteriorate of marketable grain quality. Early detection of pathogens is a crucial step in the diagnosis as well as for the management programs in wheat (Majumder D., et al., 2013: 500-507). Seeds commonly contain high microbial loads, ranging between $10^{3}$ and $10^{6} \mathrm{CFU} / \mathrm{g}$ which are constituted mainly of pseudomonads, enterobacteria, lactic acid bacteria and yeast (Prokopowich D. and G. Blank 1991: 560-562, Randazzo, C., et al., 2009: 484-490 \& Robertson, L.J., et al., 2002: 119-'126). These levels can increase during sprouting, reaching populations as high as $10^{8}-10^{11} \mathrm{CFU} / \mathrm{g}$ (Ghandi, M. and K.R. Matthews 2003: 301-306, Penas, E., et al., 2008: 698-705 \& Peles F., et al., 2012:53-60). Therefore, to minimize microbial contamination of seedlings prior to consumption, initial microbial load should be controlled (Akbas M. Y. and Olmez H. 2007: 619-624).

Naturally happening wheat grains and their products toxicants can antagonistically affect the nutritional quality and safety of foods. Because of a growing concern about relationships between diet and diseases and because of a growing need to improve the quality and safety of our food supply, research is needed to define conditions that minimize the levels of microbial effect compounds wheat germination and growth. Thus, in order to improve wheat grains safety, there is a need for technologies to inactivate or inhibit pathogenic microbes with essential oils of hyssop that is neutral on environment and compatible natural compounds and plant extracts.

Essential oils can act as prooxidants affecting inner cell membranes and organelles such as mitochondria (Betts 2001: 33-46, Pichersky et al., 2006: 808-811). Depending on type and concentration, they exhibit cytotoxic effects on living cells but are usually nongenotoxic. Because of the great number of constituents, essential oils seem to have no specific cellular targets. As typical lipophiles, they pass through the cell wall and cytoplasmic membrane, disrupt the structure of their different layers of polysaccharides, fatty acids and phospholipids and permeabilize them. Cytotoxicity appears to include such membrane damage. In bacteria, the permeabilization of the membranes is associated with loss of ions and reduction of membrane potential, collapse of the proton pump and depletion of the ATP pool (Knobloch et al., 1989: 119-128, Sikkema et al., 1994: 8022-8028, Helander et al., 1998: 3590-3595, Ultee et al., 2002: 1561-1568, Di Pasqua et al., 2006: 27452749, Turina et al., 2006:101-113) Essential oils can coagulate the cytoplasm and damage lipids and proteins. Damage to the cell wall and membrane can lead to the leakage of macromolecules and to lysis the pathogenic microorganisms (Bakkali F., et al., 2007: 446-475).

\section{Methods and materials} oils

Experimental site and extraction of the essential

The study was performed in the laboratory of Microbiology at Department of Biotechnology, Faculty of Biology and biotechnology al-Farabi Kazakh National University. To prepare essential oils, seeds of hyssop were collected from Panjshir province of Afghanistan after the harvesting process and storage at room temperature for 5 days (Shokouhian A., et al., 2016:13-17).-General methods such as steam distillation or isolation with water without any solvents are used in industrial sectors obtain of hyssop essential oils (Jirasek V., et al., 1986: 15-16). To study the effectiveness of vary solvents and their effect on the quantity and composition of essential oil of hyssop was isolated by petroleum ether, ethylene oxide and dichloromethane. The time period of extraction was from 1 to 90 minutes at temperatures of (in petroleum ether $50^{\circ} \mathrm{C}$, in ethylene oxide $-5^{\circ} \mathrm{C}$ and in dichloromethane $20^{\circ} \mathrm{C}$. The best result was received with petroleum ether at $50^{\circ} \mathrm{C}$ for 90 minutes. The 
method was more effective than other methods, the essential oils production of hyssop raised from $0,92 \%$ extract ethylene oxide and dichloromethane to $1,49 \%$ extracted by petroleum ether.

The isolated oily liquid $0,15-0,76 \%$ pigments are light yellow in color, of pleasant spicy, herb-like, slightly camphoraceous smell with $\rho=0,917-0,965$; $\alpha=-6^{\circ}$ to $-25^{\circ}$; acid number $\leq 4$. According to some scholarly sources the hyssop (Hyssopus officinalis) contains more than $1 \%$ of essential oil with maximum content at the onset the flowering stage. The content of essential oils $(0,90-0,92 \%)$ in plants of Hyssopus officinalis var. seravschanicus demonstrated grown in the area Sukhandarya in Russia is almost in agreement with the latter reference. Leaves had the highest content of essential oil at the stage of budding formation (Kizil S., et al., 2008: 273-279, Diaconu P. and Birza T. 1991: 13-16). Newer papers report higher contents - up to $7 \%$ - in relation to genotype as displayed by analyses of the hyssop (Hyssopus officinalis) population grown in 19851990. The essential oil enable to find in 6 phenotype representatives (corolla color from dark blue to white) was conditioned by flower color (higher content was found in darker-color individuals). Shoots without leaves and non-green plant parts did not contain any essential oil (Jankovsky M. and T. Landa 2012:119-123).

\section{Seed treatment and collection of the data}

Petri-plates containing nutrient agar medium were double streak technique and put into the incubator for 24 hour and plates were incubated at $37{ }^{\circ} \mathrm{C}$. Already by using pour plate and spread plate techniques isolated the bacterial contains (Pseudomonas aeruginosa, Bacillus subtilis, Staphylococcus aureus) of all wheat seeds varieties (Mukawm, Chunta, Ghory, Sosan, Sulh 2002, Akozet, Farblang and Parwa) and save into the test tubes in cool temperature inside the freezer. After re-cultivated of bacteria by adding $10 \mathrm{ml}$ of solvent $0.5 \% \mathrm{NaCl}$ enable to pour from petri to test tubes and 10 seed of wheat in each of specific tubes again put to the incubator for 2 hour in $37^{\circ} \mathrm{C}$. Thus we had four variant Control, bacterial inoculant, treated and essential oils. Ten wheat seeds were kept in each Petri plate containing two disks of Whatman No.1 filter and the experiment was conducted in duplicate (Perello A., et al., 2013: 318-332). Observation on seed germination was taken for five days. The experiment was conducted at room temperature of 25 $+1^{\circ} \mathrm{C}$ and 12 hour light and the same darkness. The germinated seeds were counted by emerging radicle elongating to $2 \mathrm{~cm}$ during 5 days of germination. The number of germinated seeds in each Petri dish was daily recorded. The germination percentage was estimated using the following simple equation:

$$
\mathrm{Ge}=\frac{\text { The number of germinated after five days }}{\text { Total number of seeds }} \times 100
$$

Indeed, the magnitude of the Ge index displays a too degree of germination for treated seeds representing high effect of essential oils on Ge. (Rani B., et al., 2014: 1055-1063).

\section{Results and discussion}

The study was referred to four variant that each of them had vary of each other effective on wheat germination and growth. The best biological compound which capable successfully controls the pathogenic fungal, viral, bacterial and insect contaminations is essential oils of hyssop (Hyssopus officinalis). The results of this experiment revealed essential oils were completely effects on bacterial inoculant and support the growth of wheat grain. It enables to eliminate the all pathogenic bacteria which inoculated with seeds.

The experiment displayed that bacterial inoculant effected on seed germination, only two varieties of wheat capable to geminate with Pseudomonas inoculated that was $40 \%$ germinated seed in Ghory cultivar and $80 \%$ germinated seed in Sulh variety. Thus shown bacterial inoculated caused to decrease 60 and 20 percentage germination of the Ghory and Sulh varieties respectively. Although in all other wheat cultivars hadn't germination in bacterial inoculated variant, but in controls (inoculant of water, inoculated with essential oil of hyssop) had $100 \%$ germination and also in Treated variants the wheat seeds germinated $80 \%$ and were greatly treated by essential oils of hyssop (Hyssopus officinalis) (Figures 1 and 2).

Thus clarified inoculated microbes enable to reduced and eliminated the wheat germination and very significant to inoculant with essential oils of hyssop for combine and prevent this peril before planting the wheat seed.

Mostly of these wheat grains after germination had died and couldn't capable to survive and growth it replayed the colonization of bacteria that appeared black spots around the hypocotyls and epicotyls of wheat seed which caused interfering by pathogenic bacteria that inoculated already with wheat grains and amount of hazard in wheat field. Also effected on 
speed of growth which causes to delay the maturity and harvesting process the growth conducted after emerging radicles five days. Generally the wheat germination of controls start at minimum $2 \mathrm{~cm}$ and prolong during five days the highest length shoot of controls variants among all of variants is Sulh variety that had $17 \mathrm{~cm}$ in essential oil and $15.7 \mathrm{~cm}$ in distillate water (Figure 3).

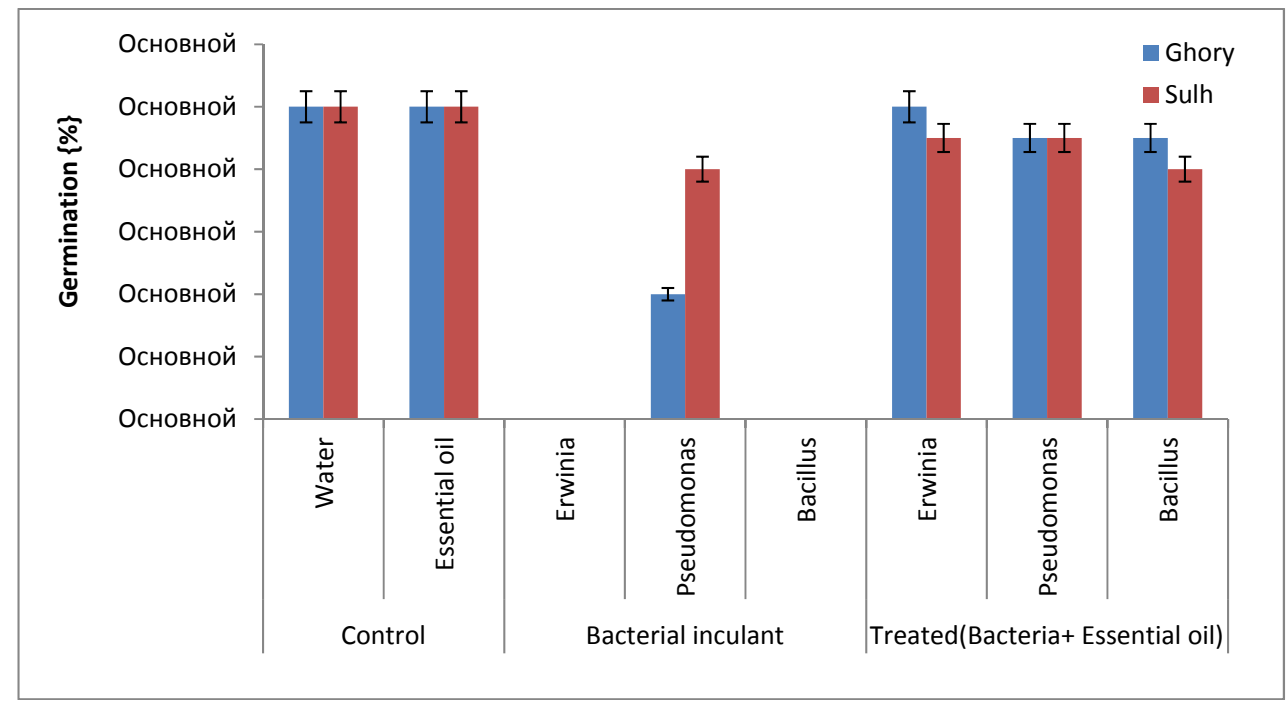

Figure 1 - Percentage of two varieties of wheat grains germination in controls and different variants contaminated with Erwinia, Pseudomonas and Bacillus

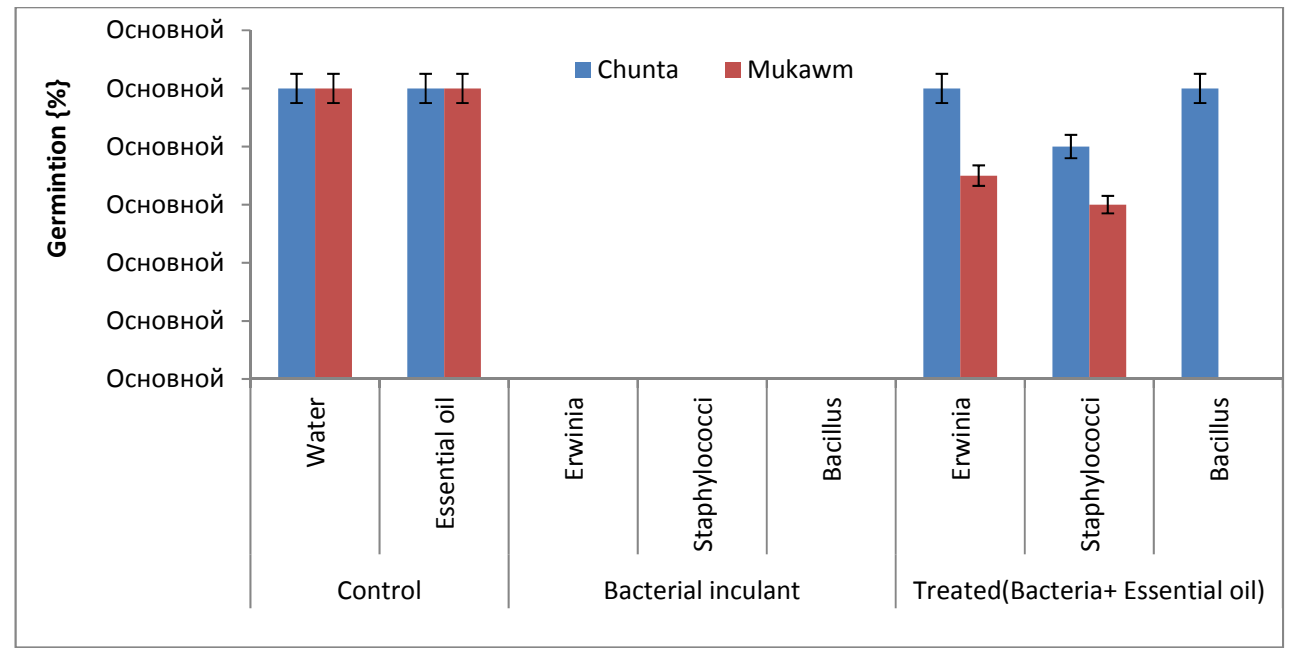

Figure 2 - Percentage of two varieties of wheat grains germination in controls and different variants contaminated with Erwinia, Staphylococci and Bacillus

Although among the bacterial inoculated variant on four varieties of wheat seeds had result that shown the resistance of wheat variety against inoculated bacteria such as Pseudomonas inoculant on Ghory and Sulh varieties, these cultivars could germinate and growth by a little different with control, the first day after germination respectively, i. e. 3,5 and $5 \mathrm{~cm}$ but in the inoculated 2 and $2,5 \mathrm{~cm}$ grew but the treated variants were satisfied because they had the same length like controls variants but a little different in Pseudomonas contaminated, i.e. the first day 5,5 and $5 \mathrm{~cm}$ treated Pseudomonas inoculated and in the controls 3,5 and $5 \mathrm{~cm}$ (Figure 4). 


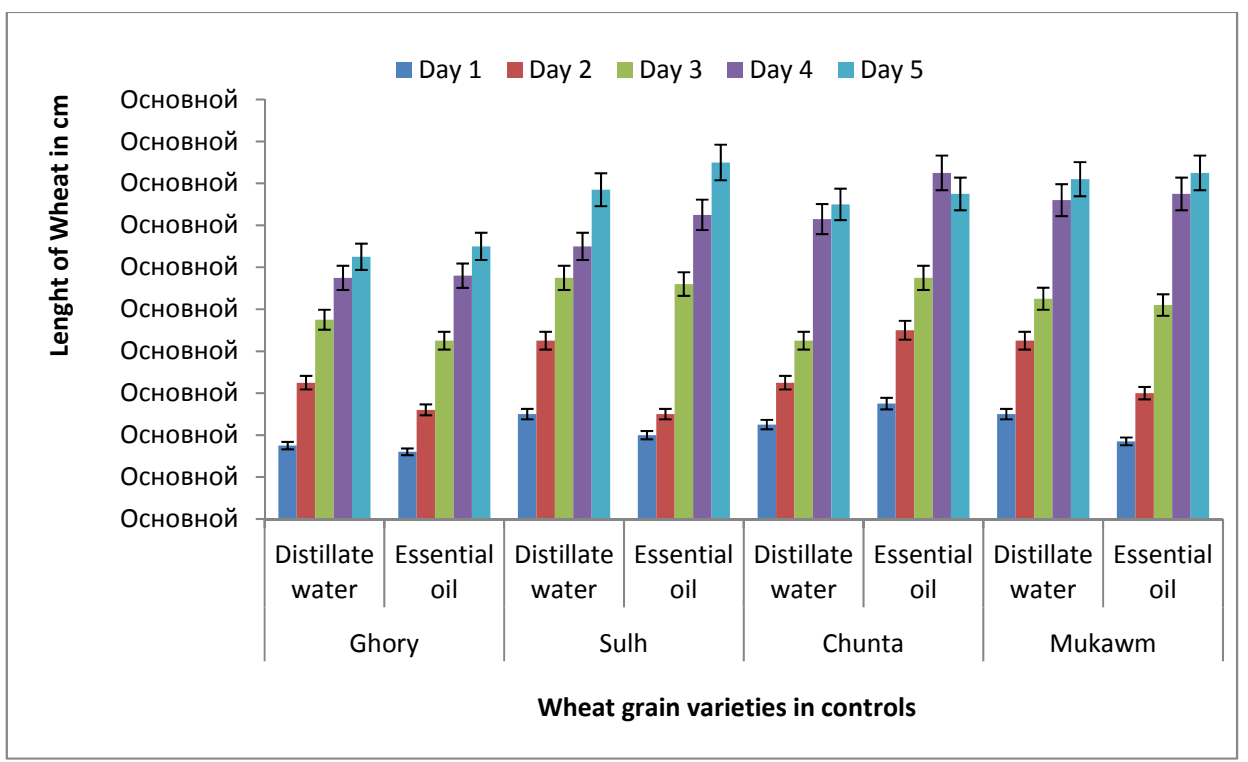

Figure 3 - Growth of four wheat varieties as controls during five days

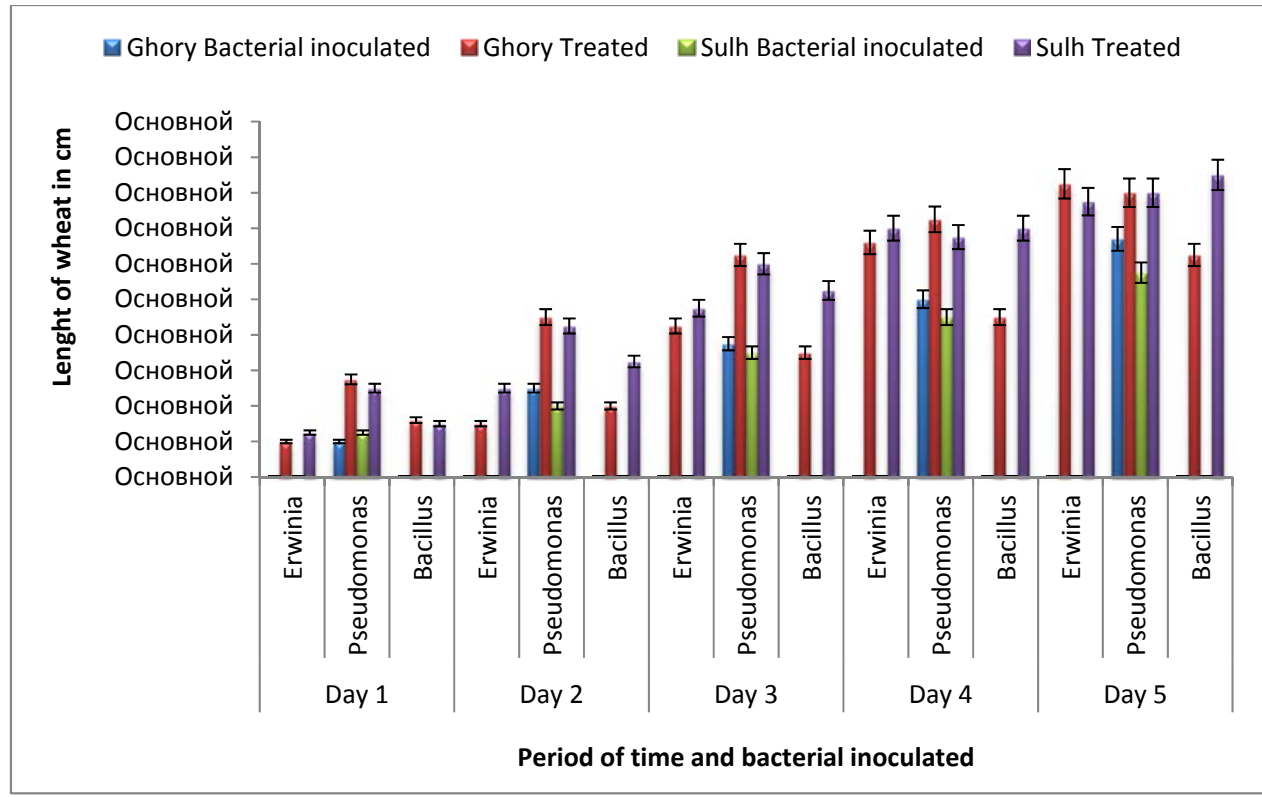

Figure 4 - Growth of Ghory and Sulh varieties in treated and inoculated during five days

But the treated variants had greatly growth Chunta variety that had the highest growth among the inoculated bacteria especially contaminated by Bacillus then Staphylococci and Erwinia treated varieties, so in the bacterial inoculated variant fully eliminated all cultivars these bacteria colonized and produced black spots the covered the wheat seeds. Thus the elimination of seeds by colonizing of bacteria revealed these bacteria enable to prevention of germinating and finally destroy the yield (Figure 5).
In fact the growth of treated variants got speed after third day of germination, so the essential oils variants grow up day by day with hadn't any difference, it replayed the essential oils of hyssop affected on bacterial inoculant during first until third day of germination and then support the growth process of wheat. And the all cultivars were susceptible against all genera such as Pseudomonas, Erwinia, Bacillus and Staphylococci but only two varieties like Ghory and Sulh were resistance against Pseudomonas. 


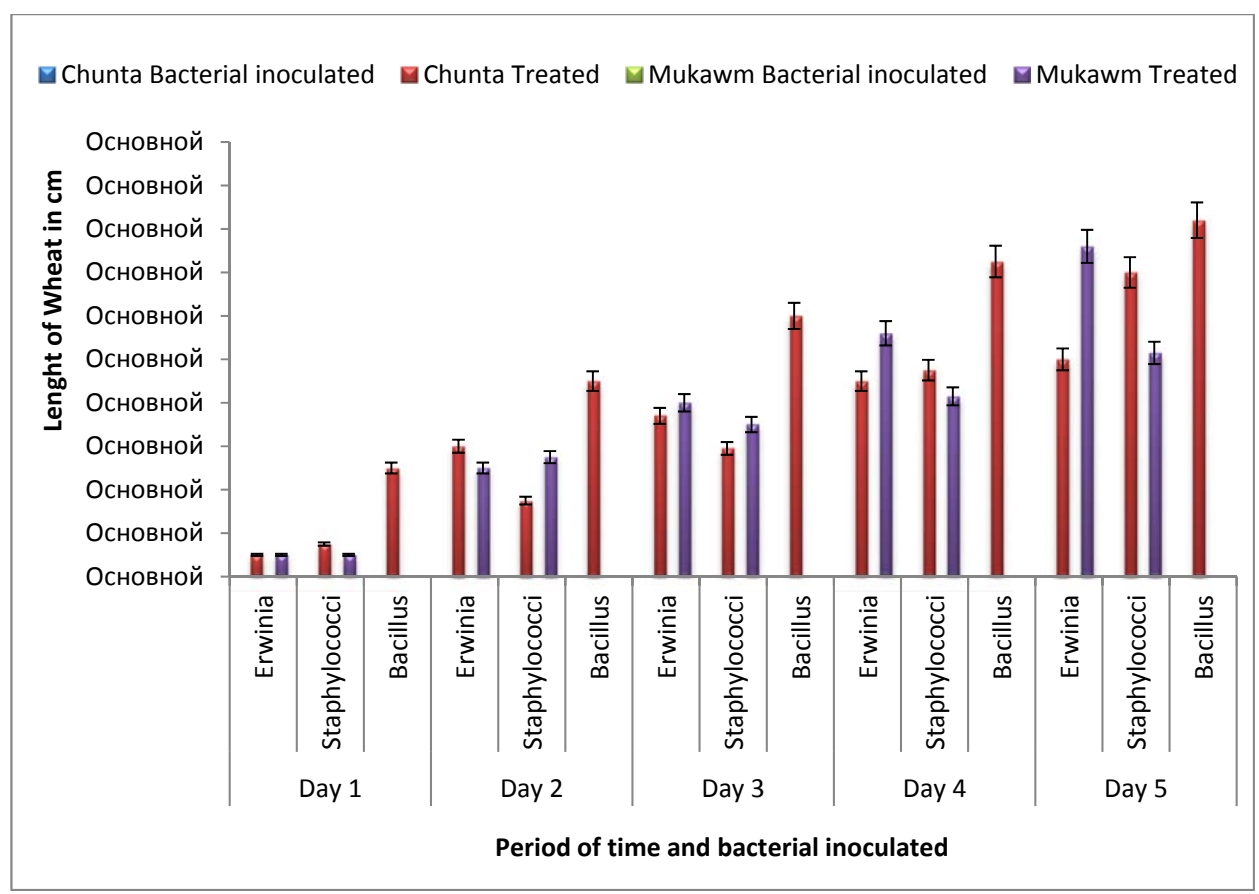

Figure 5 - Growth of Chunta and Mukawm varieties in treated and inoculated during five days

\section{Conclusion}

This study received among which bacteria were sensitive against essential oils of hyssop, although they had difference level effecting such as Bacillus the highest sensitive versus essential oils of hyssop in all varieties of wheat seeds successfully controlled and the growth of wheat seeds lengths the same in controls variant in case the inoculated variant eliminated the wheat seed for example in Chunta variety at the control was grown during five days like $4,5 \mathrm{~cm} 6,5 \mathrm{~cm} 8,5 \mathrm{~cm}$ $14,3 \mathrm{~cm}$ and $15 \mathrm{~cm}$ but on the treated variant also was grown at the period of five days that consist respectively as $5 \mathrm{~cm} 9 \mathrm{~cm} \quad 12 \mathrm{~cm} 14,5 \mathrm{~cm}$ and $16,4 \mathrm{~cm}$. The Erwinia and Staphylococci genera also were sensitive but not like Bacillus in Chunta and Mukawm varieties.

Thus revealed inoculated bacteria were very sensitive against essential oils of hyssop and the extraction of essential oils of hyssop is not very complex also by using of this compound we can prevent of environmental pollution and other hazard of using chemical compound that causing resistance like bacteria via conjugation or transformation, only we need to add $10.2 \mathrm{ml} /$ lit of essential oil in distillate water and inoculate the wheat seeds with this solvent before cultivation.

\section{References}

1 Satish S., Raghavendra M.P., Raveesha K.A. «Management of seed borne fungal pathogens of sorghum seeds by aqueous extract of Lawsonia inermis L.» Journal of Biopest 3 (1) (2010) : 237-241.

2 Abd El-Baky H.H. «Enhancing antioxidant availability in grains of wheat plants grown under seawater stress in response to microalgae extracts treatments.» Afr. Journal of Biochem Res. 3 (4) (2009): 77-83.

3 Abawi GS, Widmer TL. «Impact of soil health management practices on soil-borne pathogens, nematodes and root diseases of vegetable crops.» App Soil Ecol 15 (2000):37-47

4 Bonanomi G, Sicurezza MG, Caporaso S, Esposito A, Mazzoleni S. «Phytotoxicity dynamics of decaying plant materials.» New Phytologist 169 (2006): 571-578.

5 Macias FA, Molinillo JM, Varela RM, Galindo JC. «Allelopathy a natural alternative for weed control.» Journal of Pest Management Science 63 (2007): 327-348.

6 Rassaeifar M, Hosseini N, Asl NHH, Zandi P, Aghdam AM. «Allelopathic effect of eucalyptus globulus'essential oil on seed germination and seedling establishment of amaranthus blitoides and cyndon dactylon.» Trakia Journal of Sciences. 11 (2013): 73-81.

7 Majumder D., Rajesh T., Suting E.G., Debbarma A. «Detection of seed borne pathogens in wheat: recent trends.» Austerely Journal of Crop Sciences 7 (4) (2013): 500-507. 
8 Prokopowich, D., Blank, G., «Microbiological evaluation of vegetable sprouts and seeds.» Journal of Food Protection 54 (1991): 560-562.

9 Randazzo, C.L., Scifo, G.O., Tomaselli, F., Caggia, C., «Polyphasic characterization of bacterial community in fresh cut salads.» International Journal of Food Microbiology 128 (2009): 484-490.

10 Robertson, L.J., Johannessen, G.S., Gjerde, B.K., Loncarevic, S. «Microbiological analysis of seed sprouts in Norway.» International Journal of Food Microbiology 75 (2002): 119-126.

11 Ghandi, M., Matthews, K.R. «Efficacy of chlorine and calcinated calcium treatment of alfalfa seeds and sprouts to eliminate Salmonnella.» International Journal of Food Microbiology 87 (2003): 301-306.

12 Penas, E., Gómez, R., Frías, J., Vidal-Valverde, C. «Application of high pressure treatment on alfalfa (Medicago sativa) and mung bean (Vigna radiata) seeds to enhance the microbial safety of their sprouts.» Journal of Food Control 19 (2008): 698-705.

13 Peles F., Z. Gyori, T. Bácskai, Zs. Szabo, M. Murvai, B. Kovacs. «Microbiological quality of organic wheat grains and sprouts.» Analele University din Oradea, Fascicula Protecţia Mediului 18 (2012): 53-60.

14 Akbas, M.Y., Olmez, H. Inactivation of Escherichia coli and Listeria monocytogenes on iceberg lettuce by dip wash treatments with organic acids. Letters in Applied Microbiology 44(2007): 619-624.

15 Betts T.J. «Chemical characterization of the different types of volatile oil constituents by various solute retention ratios with the use of conventional and novel commercial gas chromatographic stationary phases.» Journal of Chromatography A 936 (2001): $33-46$.

16 Pichersky E., Noel, J.P., Dudareva, N. «Biosynthesis of plant volatiles: nature's diversity and ingenuity.» Journal of Science 311(2006): 808-811.

17 Knobloch K., Pauli, A., Iberl, B., Weigand, H., Weis, N.,. «Antibacterial and antifungal properties of essential oil components.» Journal of Essential Oils Res. 1(1989) 119-128.

18 Sikkema J., De Bont J.A., Poolman B. «Interactions of cyclic hydrocarbons with biological membranes.» Journal of Biological Chemistry 269 (1994) 8022-8028.

19 Helander I.M., Alakomi, H.L., Latva-Kala, K., Mattila-Sandholm, T., Pol, I., Smid, E.J., Gorris, L.G.M., Von Wright, A. «Characterization of the action of selected essential oil components on Gramnegative bacteria.» Journal of Agriculture Food Chemistry 46 (1998):3590-3595.

20 Ultee A., Bennik, M.H., Moezelaar, R., 2002. The phenolic hydroxyl group of carvacrol is essential for action against the food-borne pathogen Bacillus cereus. Appl. Environ. Microbiol. 68, 1561-1568.

21 Di Pasqua R., Hoskins, N., Betts, G., Mauriello, G. «Changes in membrane fatty acids composition of microbial cells induced by addiction of thymol, carvacrol, limonene, cinnamaldehyde, and eugenol in the growing media.» Journal of Agriculture Food Chemistry 54 (2006): 2745-2749.

22 Turina A.V., Nolan, M.V., Zygadlo, J.A., Perillo, M.A. «Natural terpenes: self-assembly and membrane partitioning.» Biophys. Chem. 122(2006): 101-113.

23 Bakkali F., S. Averbeck, D. Averbeck, M. Idaomar. «Biological effects of essential oils.» Science Direct Journal, Food and Chemical Toxicology 46 (2008): 446-475.

24 Shokouhian A., Hassan Habibi, Kayvan Agahi. «Allelopatic effects of some medicinal plant essential oils on plant seeds germination.» Research articles Tehran 33191-18651, Iran 5(1) (2016): 13-17.

25 Jirasek V., Stary F., Severa F. «Kapesni atlas lecivych rostlin.» Praha, SPN. (1986): 15-16.

26 Kizil, S., Toncer, O., Ipek, A., Arslan, N., Saglam, S. and K.M. Khawar. «Blooming stages of Turkish hyssop (Hyssopus officinalis L.) affect essential oil composition Acta Agriculturae Scandinavica» Section B-Soil \& Plant Science 58(3) (2008): $273-279$.

27 Diaconu P., Birza T. «Studies on variation in the species Hyssopus officinalis L. (hyssop).» Lucrari Stiintifice Seria A: Agronomie 34 (1991): 13-16.

28 Jankovsky M., T. Landa. «Genus Hyssopus L. - recent knowledge.» Czech University of Agriculture, Faculty of Agronomy, Prague, Czech Republic (2012): 119-123.

29 Perello A., Martin G., Alan J. S. «Effect of garlic extract on seed germination, seedling health, and vigour of pathogeninfested wheat.» Journal of plant protection research 53 (4) (2013): 318-332.

30 Rani B., Vivek Kumar, Jagvijay Singh, Sandeep Bisht, Priyanku Teotia, Shivesh Sharma and Ritu Kela. «Bioremediation of dyes by fungi isolated from contaminated dye effluent sites for bio-usability.» Brazilian Journal of M icrobiology 45 (3) (2014): $1055-1063$ 